DOI: 10.15393/j9.art.2019.6061

УДК 821.161.1.09“18”

Наталья Павловна Жилина

(Калининград, Российская Федераиия)

nzhilina@rambler.ru

\title{
Идея спасения в думе К. Ф. Рылеева «Владимир Святый»
}

Аннотация. Религиозный контекст творчества К. Ф. Рылеева до сих пор оставался в основном за пределами внимания ученых. Дума «Владимир Святый», не публиковавшееся при жизни поэта произведение, рассматривается в аксиологическом ракурсе, что позволяет по-новому интерпретировать ее центральный конфликт. Анализ художественной структуры думы дает возможность увидеть, что ее сюжет в целом ряде важных деталей отступает от исторического источника, а на первый план выдвигается оппозиция «христианство / язычество», в которой реализуется антитеза истинных и ложных ценностей. Мотив совести, занимающий в сюжете произведения важнейшее место, напрямую связывает идейную систему с христианской антропологией. В связи с этим устойчивая и привычная для романтизма мотивация отчуждения главного героя от мира трансформируется, что позволяет говорить об идее спасения как центральной и сюжетообразующей в произведении. Финал производит впечатление фабульной незавершенности, поэтому заглавие произведения предвосхищает грядущие события, а все изображенное в думе является лишь той исходной ситуацией, с которой начинается путь князя к святости.

Ключевые слова: К. Ф. Рылеев, дума, князь Владимир, сюжет, мотив, христианство, язычество

Об авторе: Жилина Наталья Павловна- доктор филологических наук, доцент, профессор, Институт гуманитарных наук, Балтийский федеральный университет им. Иммануила Канта (236016, Российская Федерация, г. Калининград, ул. Александра Невского, 14)

Дата поступления: 15.03.2019

Дата публикации: 09.09.2019

Для цитирования: Жилина Н. П. Идея спасения в думе К. Ф. Рылеева «Владимир Святый» // Проблемы исторической поэтики. - 2019. - Т. 17. — № 3. - C. 25-43. DOI: 10.15393/j9.art.2019.6061

$\Upsilon$ ворчество поэтов-декабристов, сыгравшее значительную
роль в отечественном литературном развитии, не было
изучено во всех аспектах. В наибольшей степени это отно-
сится к наследию К. Ф. Рылеева, первые работы о котором

( Н. П. Жилина, 2019 
появились в России лишь в начале XX в., после гибели поэта: автор первой монографии Н. Котляревский [Котляревский] стремился, прежде всего, показать Рылеева как личность, а книга В. И. Маслова [Маслов] содержала полноценный литературоведческий анализ творчества. Отношение к Рылееву резко изменилось после октября 1917 г.: открылись большие возможности для публикации и изучения его наследия, однако это сопровождалось определенным искажением в интерпретации его произведений, поскольку основное внимание акцентировалось на их революционном содержании. После Великой Отечественной войны внимание к творчеству Рылеева усилилось: наряду с работами, освещающими прежде всего его общественную и революционную деятельность [Нейман], [Пигарев], появились и глубокие исследования его поэтического наследия [Цейтлин].

В 1960-1980-е гг. изучение творчества Рылеева вышло на новый уровень: кроме работ, посвященных биографии поэта, публикуются в большом количестве и труды аналитического характера. Важнейшим объектом изучения в эти годы остается, как и прежде, политический контекст его творчества, однако центр внимания ученых теперь сдвигается в сторону других проблем: художественного метода, жанровой специфики, особенностей стиля. Анализируя различные поэтические системы, утверждающиеся в русской литературе в первые десятилетия XIX в., Л. Я. Гинзбург делает вывод: «Для гражданской, политической поэзии 10-20-х годов область высших достижений - не лирика. В декабристских кругах наиболее серьезное значение придавали драматургии (“Горе от ума”, “Аргивяне” Кюхельбекера) и опытам в эпическом и полуэпическом роде: баллады и эпические стихи Катенина, думы и поэмы Рылеева» [Гинзбург: 27]. С этим связано и то пристальное внимание, которое проявляли ученые именно к этим жанрам.

В конце ХХ в. интерес к Рылееву заметно снизился, его творчество оказалось на периферии внимания большинства историков литературы. За последние два десятилетия, в 2000-2019 гг., появилось лишь несколько значительных публикаций, посвященных творчеству поэта ${ }^{1}$. 
При всей многочисленности работ, опубликованных в разные периоды, следует признать, что за все время изучения творчества Рылеева за пределами внимания ученых практически полностью остался важнейший аспект исследования религиозный. Между тем невозможно не согласиться с мыслью В. Н. Захарова, высказанной им в середине 1990-х гг., о том, что в XX в. «много сказано о национальном своеобразии русской литературы, но не сказано убедительно главное: русская литература была христианской. <...> Если верить школьным и университетским учебникам, то русская литература всех веков была озабочена государственными деяниями, а последние два века только и делала, что готовила и осуществляла революцию» (курсив мой. - Н. Ж.) [Захаров, 1994: 5]. В наибольшей степени это положение относится к творчеству поэтов-декабристов и особенно Рылеева. Нужно признать, что идеологические установки, распространявшиеся в те годы на всю гуманитарную науку, оказывали серьезное влияние и на методологию анализа художественных текстов. Следовательно, в настоящее время многие из них нуждаются в новом прочтении.

Цикл оригинальных произведений, создававшийся Рылеевым в 1820-е гг, имел ту же дидактическую установку, что и вся поэзия декабристов: воздействовать на молодые умы, просвещая их и воспитывая настоящих граждан своего Отечества, готовых отдать жизнь за общественное благо. Среди советских ученых преобладало мнение о том, что «понятие “высокого” и “к добру увлекающего” в декабристском лексиконе <...> равнозначно понятию революционной цели» [Левкович: 151]. В таком случае трудно объяснить тот факт, что главными героями в трех текстах цикла являются канонизированные Русской православной церковью святые: Равноапостольные Ольга и Владимир, а также Святой благоверный князь Михаил Тверской. Ольга и Владимир прославились своими масштабными делами по укреплению и развитию русской государственности, однако церковь никогда не удостаивает чина святости даже за самые великие земные деяния, а только лишь за духовные подвиги. На это указывает и сама номинация чина: «равноапостольный - святой, который 
много способствовал распространению христианства в какойлибо области или стране»², «благоверный - царь или князь, много способствовавший укреплению православной веры и причисленный Церковью к лику святых»³. Таким образом, приходится признать, что при выборе своих героев Рылеев руководствовался не только критериями узко понятой гражданственности. Ярким примером этому является сюжет думы «Владимир Святый», имеющий в своей основе «летописные данные в передаче Карамзина» [Архипова, Ходоров: 432].

Личность князя Владимира Святославича привлекала особое внимание летописцев и историков, поскольку биография его полна удивительных событий и необычных поворотов судьбы. Напомним, что его отец, Святослав Игоревич, сын княгини Ольги, после ее смерти продолживший дело своей матери по укреплению и развитию Русского государства, еще при жизни определил каждого из трех своих сыновей на княжение в различные уделы: Ярополка - в Киев, Олега - в Древлянскую землю, Владимира - в Новгород. Вскоре после этого великий князь погиб во время похода. Через несколько лет после его смерти между старшими Святославичами начались раздоры: Ярополк пошел войной на Олега и стал виновником его гибели. Увидев угрозу и для себя, Владимир покинул вотчину и отправился на историческую родину к варягам, а через некоторое время, собрав войско, вернулся и объявил войну старшему брату. Очистив родной Новгород от наместников Ярополка, он завоевал Киев, а затем хитростью заманил брата к себе, организовав его убийство. Так Владимир Святославич занял место великого князя и стал правителем всей Руси.

Находясь у власти, Владимир не только расширил, но и значительно укрепил Русское государство, покорив различные племена и присоединив к своим владениям обширные территории. Очень активной была и его внешнеполитическая деятельность: за время правления Владимира было заключено немало выгодных договоров с правителями соседних государств - Венгрии, Польши, Чехии и Византии. Но главной заслугой князя перед Отечеством и народом стало, как известно, Крещение Руси - событие, с которого начался новый 
отсчет в жизни всего государства. Глубокую и точную характеристику оно получило в работе В. Н. Захарова: «Русские князья Олег, Игорь, Ольга, Святослав, Ярополк, Владимир кто мечом, кто правом, кто хитростью и коварством - собрали Русские земли и подтвердили свое право на княжеский престол. Среди них были первые христиане. У них возникла потребность в новой вере. Одно дело завоевать и собрать земли, другое дело - удержать людей во власти, объединить их не силой, но духом. И сделал это Святой Владимир» [Захаров, 1998: 13].

Князь Владимир Святославич стал не только крупнейшей фигурой в российской истории, но и одним из ярких образов фольклорных и литературных произведений. «Князь Владимир стольно-киевский» появляется в сюжете былин ${ }^{4}$. Народное сознание, наградив Владимира Великого прозвищем «Красное Солнышко» и эпитетами «славный» и «ласковый», воплотило в былинах обобщенный образ идеального правителя, мудрого и решительного, организующего защиту Киева и всей Руси от врагов. В то же время изображение в характере былинного Владимира низких, темных черт, проявление которых послужило причиной его ссор с богатырями, не соотносится с описанием персонажа в летописных источниках и, таким образом, не способствует сближению этого образа с историческим «прототипом».

Совершенно иной подход можно увидеть в одном из самых первых художественных текстов XVIII столетия - трагедокомедии Феофана Прокоповича «Владимир» (1705). Именно с этой пьесы в русской драматургии начинается традиция использования материала отечественной истории для сюжета произведений, и среди ее непосредственных источников числятся русские летописи [Стенник: 39]. Основой драматической коллизии здесь является идея князя Владимира сменить веру, а все события, организующие сюжет, связаны с его борьбой за Крещение Руси. Внешний конфликт с противниками новой религии осложняется душевной борьбой Владимира, которому приходится преодолевать множество соблазнов и искушений - таким образом, автор предпринимает попытку изображения внутреннего мира героя. Владимир Креститель 
предстает в этой пьесе великим человеком, которому Истина была открыта свыше и который повел Россию по пути ее обретения.

В дальнейшем образ князя Владимира Святославича привлек внимание писателей лишь через несколько десятилетий, во второй половине XVIII в., давая материал для различных интерпретаций в связи с постановкой проблем, связанных с личностью монарха. В пьесах Я. Б. Княжнина («Владимир и Ярополк», 1772) и Ф. П. Ключарева («Владимир Великий», 1779) в характере центрального действующего лица не отражаются черты исторической личности, а проблема истинности веры и поисков религии не затрагивается.

Иную картину можно увидеть у М. М. Хераскова, в произведениях которого князь Владимир Святославич как главный герой появляется дважды. В трагедии «Идолопоклонники, или Горислава» (1782) Херасков представил свою интерпретацию летописного предания, повествующего о неудачной попытке полоцкой княжны Рогнеды («названной по ее горестям Гориславою» [Карамзин: 147]), убить спящего князя Владимира. Герой предстает перед читателем в тот момент, когда в его душе уже произошел переворот и он готов отказаться от прежней религии. Главное, что привлекает великого князя в христианстве, - это нравственный закон любви и добра, которого ему не хватает в языческих культах. Двойное название трагедии эксплицирует сложность ее художественной структуры: за внешним конфликтом, отражающим взаимоотношения Владимира и Гориславы, четко просматривается другой, идеологический: его основой является жестокое противоборство язычников со своим правителем, решившим принять христианство. В трагедии Хераскова милосердие утверждается как главный принцип монарха, избравшего нравственность своим высшим приоритетом и решившего вести свой народ по этому пути.

Если в трагедии «Идолопоклонники, или Горислава» событие Крещения Руси только намечается, то в эпической поэме «Владимир» (1785) оно составляет семантический центр. В сюжетной структуре поэмы центральной также является оппозиция христианство / язычество, но художественный 
конфликт здесь обретает бо́льшую остроту: в его основе лежит противоборство сил Добра и Зла, а полем битвы оказывается душа князя Владимира. Цепь многочисленных событий (как исторических, так и вымышленных) в произведении выстроена таким образом, чтобы читатель мог следить за метаморфозами главного героя. Следуя в целом довольно точно летописному изложению, Херасков сосредоточивается на преображении и возрождении души великого князя - не случайно в первом издании поэма носила название «Владимир возрождённый». История в поэме соотносится с темой веры и самоопределения героев. Сюжетную канву составляет мистический путь князя Владимира: от состояния внешнего благополучия вкупе с душевной скудостью (в котором пребывают он сам и его подданные) - к духовной вершине, которая может быть обретена только огромными усилиями.

Рассмотрев произведения различных авторов, главным героем которых стал князь Владимир Святославич, можно говорить о том, что в русской литературе XVIII в. (за исключением текстов, где сюжетная канва имеет внеисторический характер) сложилась определенная традиция изображения этого исторического лица и связанных с ним событий. Главным объектом авторского внимания становится, как правило, внутренний мир князя в период, связанный со сменой религий, и его борьба за Крещение Руси, а основу художественного конфликта составляет оппозиция христианство / язычество. Продолжение этой традиции можно увидеть и в творчестве К. Ф. Рылеева.

Заглавие думы Рылеева - «Владимир Святый» - настраивает читателя на то, что сюжет будет организован вокруг важнейшего момента в жизни князя и всей Руси - Крещения. Однако текст думы опровергает эти предположения. Фабульной основой произведения становится ситуация, для которой, казалось бы, нет никаких реальных жизненных или психологических оснований: великий князь, одержавший к этому времени множество важных и громких побед, чье имя прославлено за пределами Руси, вдруг оказывается сраженным тяжелым душевным недугом. 
Стоит отметить, что сюжетная организация думы соответствует тем принципам, которые вошли в русскую литературу с поэмами Дж. Г. Байрона и А. С. Пушкина: практически отсутствует вступление, действие сосредоточено вокруг главного героя, внутренний мир которого является основным объектом внимания автора [Жирмунский: 43]. Как это нередко бывало у великих предшественников Рылеева, поэтическое изложение начинается с описания центрального действующего лица:

«Ни гром побед, ни звуки славы, Ничто Владимира утешить не могло, Не разъясняли и забавы Его угрюмое и мрачное чело.... ${ }^{5}$.

Необходимо напомнить, что в романтической поэме одним из основных является тип «разочарованного» героя. На него ориентирует читателя экспозиция думы, где происходит знакомство с героем. Психологическое состояние князя Владимира передается традиционными романтическими приемами: он изображен в характерной и весьма выразительной позе («...с привычной думой // На длань склонен главой, уединясь, сидел...» - 177), назван «страдальцем» и сам признается, что «ужасные мученья» его «преследуют и в шуме и в тиши» (177); он рассеян на «светлых пиршествах» и дичится радостей, увлекавших его прежде. Итак, в полном соответствии с романтическими канонами, князь Владимир одинок, мрачен и безутешен. Налицо отчуждение его от мира - главный признак «разочарованного» героя. Однако в противоположность сложившейся традиции причиной страданий в данном случае является не безответная любовь, не гибель возлюбленной, а страшный грех братоубийства, совершенный задолго прежде, но напомнивший о себе лишь сейчас.

Важно заметить, что Владимир за братоубийство не подлежал никакому суду не только из-за своего статуса, но и потому, что в дохристианскую эпоху на Руси вообще отсутствовали правовые институты. Человека защищал не закон, а обычай: за преступление (которое тогда считалось «обидою»), «должен был отплатить, “отомстить” сам обиженный или его род. <...> Обычай “кровной мести” и вообще “мести” был так 
широко распространен, что признавался даже законом, как нормальное правило» [Платонов: 110-111]. Кроме того, нельзя не признать, что Ярополк первым нарушил установленный их отцом порядок и стал виновником междоусобной войны. Однако, как показывает Рылеев, в душе великого князя неожиданно для него самого вдруг проявилась власть другого закона - закона совести, муки которой не заглушались обращением к языческим богам.

По библейским представлениям, сотворив человека «из праха земного», Бог «вдунул в него дыхание жизни, и стал человек душою живою» (Быт. 2:7). Как указывает известный богослов митр. Иларион (Алфеев), “"дыхание жизни” можно понимать как Святой Дух (и “дыхание”, и “дух” в греческой Библии обозначаются одним термином рпеита)» [Иларион: 78]. Таким образом, «будучи “перстным”, земным, человек получает некое Божественное начало, залог своей приобщенности к Божественному бытию» [Иларион: 78]. И это божественное начало выражается в особых качествах, не присущих никаким божьим творениям, кроме человека.

Согласно христианской антропологии, главным из этих качеств, непосредственно данных лишь человеку, является Божественный нравственный закон, который призвана контролировать совесть. Осознание преступности своих поступков и есть то действие, которое производит в сердце человека совесть, пробуждающая в душе страх не столько юридического наказания, сколько Божьего гнева. Определенно и точно на это указывается в святоотеческой литературе: «Когда Бог сотворил человека, то Он всеял в него нечто Божественное, как бы некоторый помысл, имеющий в себе, подобно искре, и свет, и теплоту; помысл, который просвещает ум и показывает ему, что доброе и что злое, - сие называется совестью, а она есть естественный закон», - писал св. авва Дорофей [Добротолюбие: 196]. В церковно-славянском словаре это понятие трактуется следующим образом: «Совесть - 1) мысль, помышление; голос Божий, показывающий ведение (отсюда со-весть) воли Божией относительно того, что должно и чего не должно делать человеку как разумно-нравственному существу» ${ }^{6}$ В словаре В. И. Даля, это понятие определяется в точном соответствии 
с христианскими представлениями: «Совесть - нравственное сознание, нравственное чутье или чувство в человеке; внутреннее сознание добра и зла; тайник души, в котором отзывается одобрение или осуждение каждого поступка; способность распознавать качество поступка, чувство, побуждающее к истине и добру, отвращающее ото лжи и зла; невольная любовь к добру и к истине; прирожденная правда, в различной степени развития». В качестве одного из примеров В. И. Даль приводит пословицу «Добрая совесть - глаз Божий (глас Божий)». Таким образом, страдания князя Владимира в сюжете рылеевского произведения вызваны действием в его душе высшего нравственного закона, о котором он ранее и не подозревал.

Вводя мотив совести (отсутствующий в «Повести временных лет»), Рылеев опирается на Карамзина, именно в таком ключе трактовавшего данную ситуацию:

«Владимир, утвердив власть свою, изъявил отменное усердие к богам языческим: соорудил новый истукан Перуна с серебряною головою и поставил его близ теремного двора, на священном холме, вместе с иными кумирами. Там, говорит Летописец, стекался народ ослепленный и земля осквернялась кровию жертв. Может быть, совесть беспокоила Владимира; может быть, хотел он сею кровию примириться с богами, раздраженными его братоубийством: ибо и самая Вера языческая не терпела таких злодеяний...» [Карамзин: 144-145].

К изложению Карамзина восходит и сюжетный ход, примененный поэтом: изнемогая от страданий, его герой обращается с мольбой к главному языческому богу - Перуну, статуя которого, согласно летописи, незадолго до этого была возведена им в центре Киева:

«Молю у твоего кумира:

Предел страданиям душевным положи, -

Пересели меня из мира

Или по-прежнему с веселием сдружи!» (177)

В противоположность Ярополку, по мнению ряда историков, питавшему определенные симпатии к христианству, особенно в его католическом варианте [Назаренко: 345], в правление Владимира происходит возвращение к язычеству, 
что было связано, по-видимому, со стремлением князя, расширяя страну, укреплять и ее идеологическое единство. В исторических источниках отмечено, что в это время Владимир построил новые капища, возвел новые кумиры языческим богам, которым приносились даже человеческие жертвы. Однако вскоре произошло охлаждение князя к прежней религии и начались поиски новой. Большинство советских историков склонялись к мнению, что это было вызвано прежде всего политическими причинами. Дело в том, что окружавшие Русь страны ко времени правления Владимира уже перестали быть языческими и приняли религии единобожия. Великий князь, видимо, понимал, что должен присоединиться к ним, но колебался в своем выборе.

«Повесть временных лет» (ставшая, в свою очередь, основой для «Истории» Карамзина), описывая ситуацию выбора веры князем Владимиром, делает упор на нескольких моментах: к Владимиру как могущественному государю прибывают послы из разных стран с предложением принять их религию; великий князь колеблется, советуется с боярами и отсылает «на разведку» своих людей, которые, прибыв обратно, советуют выбрать греческую веру.

Согласно этому летописному источнику, Владимир отверг предложения послов «магометанской веры», «иноземцев из Рима», а также «хазарских евреев» ${ }^{8}$, указав им причины своего отказа, но внимательно выслушал греческого философа, вкратце изложившего князю по его просьбе всю библейскую историю и оказавшего на выбор Владимира огромное влияние. В думе Рылеева из всех послов остается лишь греческий философ, изображенный в виде неизвестного старца, держащего в руках распятие и представляющегося «послом Творца» (177). Он появляется в тот самый момент, когда герой дошел в своих страданиях до предела. Эмоциональный рассказ философа о Страшном Суде и последствиях нераскаянных грехов для каждого человека производит на великого князя неизгладимое впечатление.

Таким образом, сюжет думы в целом ряде важных деталей отступает от исторического источника. Прежде всего, определенно показано, что главная причина отказа великого князя 
от прежних верований лежит в плоскости психологии. Как и у некоторых предшественников Рылеева (Прокопович, Херасков), события описываются так, что читателю становится ясно: в мировоззрении Владимира произошли кардинальные перемены - то, что считалось в язычестве и всегда воспринималось самим князем как норма, теперь ощущается им как страшный грех. Он отказывается от прежних богов, у которых не может найти душевного успокоения, и с надеждой обращается к смиренному старцу, объяснившему причину его мучений: «Ты Бога вышнего делами прогневил...» (177). Нарисовав весьма живописную картину посмертной судьбы грешника, «пришлец священный» (178) слышит главный вопрос князя: «О, чем же я избегну ада?» — и дает точный ответ:

«Крести себя, крести народы! -

В ответ вещал святой, - и ты себя спасешь!» (178).

Чрезвычайно важно, что в думе Рылеева (как и в пьесе Ф. Прокоповича) нет ситуации выбора из нескольких монотеистических религий. Владимир должен определиться между язычеством - традиционной верой предков - и совершенно новым для него христианством, и он делает выбор не на основе сравнения (как это показано в исторических источниках), не в результате логических рассуждений, а интуитивно, под влиянием тех чувств, которые испытывает измученная страданиями грешная душа в поисках спасения. Степень доверия князя к незнакомцу (выраженная в его фразе: «Из твоего читаю взгляда, / Что ты, таинственный, спасти меня притек!..» - 178) убеждает читателя, что идея спасения в сознании Владимира теперь неразрывно связана с представлением о христианской религии, проповедником которой является святой старец. Именно этим обусловлено окончательное решение Владимира:

«“Крести ж, крести меня, о дивный!” -

В восторге пламенном воскликнул мудрый князь...» (179).

Принявший судьбоносное для всей страны решение герой Рылеева наделяется эпитетом «мудрый», однако в его дальнейших действиях намечается расхождение с этой характеристикой. «Новый подвиг», на который Владимир «полетел» 
«с новым жаром», представляется ему очередным завоеванием, в предвидении которого уже «трепещет Греция и гордые цари!..» (179). В последнем стихе голос автора окрашивается интонацией главного героя, с восторгом предчувствующего будущую победу. Его глазами воспринимается и восход солнца, как будто обещающий грядущие сражения: «Зарделись небеса пожаром...» (179).

Дистанция между автором и героем в оценке происходящих событий хорошо видна в заключительной строфе произведения, где состояние души князя передается образом огня, коррелирующим с картиной небесного «пожара»:

«Так в князе огнь души надменной, Остаток мрачного язычества горел:

С рукой царевны несравненной

Он веру самую завоевать летел...» (179).

Словосочетание «огнь души надменной» благодаря эпитету имеет явную негативную коннотацию, которая подкрепляется следующим далее уточнением «остаток мрачного язычества», а последние два стиха строфы наполнены неприкрытой авторской иронией: вера мыслится князем как нечто материальное, поддающееся завоеванию так же, как чужая территория, города и страны.

Дума «Владимир Святый» не была включена Рылеевым в отдельное издание, как считалось долгое время, по цензурным причинам. Это утвердившееся в советской науке мнение было оспорено В. Вацуро, который высказал предположение, что произведение по неизвестным причинам осталось незаконченным. «Можно думать, - писал исследователь, - что Рылеев оставил работу над этой думой, оборвав ее посередине» [Вацуро: 102]. По мнению ученого, в тексте должен был быть воспроизведен весь сюжет крещения, изложенный Карамзиным: приезд царевны Анны в завоеванный Владимиром Корсунь, внезапная слепота и последующее исцеление князя, повлекшее за собою его «прозрение». Именно здесь, считает исследователь, «заключалась моралистическая идея посрамления гордыни земного владыки - и есть некоторые основания полагать, что дума писалась отчасти и на эту тему» $[\mathrm{Ba}-$ цуро: 102]. 
Не отвергая выдвинутую авторитетным ученым гипотезу, отметим, что и в данном виде можно рассматривать «Владимира Святого» как целостный текст, причем его сюжетная «незавершенность», «оборванность» на кульминационном моменте производит неожиданный и весьма яркий эффект. Заглавие произведения - «Владимир Святый» - предвосхищает грядущие события; изображенное в думе является лишь той исходной ситуацией, с которой начинается путь князя к святости. Восприятие главного героя думы, стремящегося «завоевать» Царство Небесное, является своеобразной иллюстрацией неверного понимания слов Спасителя «Царство Небесное силою берется» (Мф. 11:12). Их глубокое и точное толкование дается в книге известного богослова Б. И. Гладкова: «Конечно, Царство Небесное берется не грубою силою, не так, как берутся, завоевываются царства земные. Царство Небесное дается, врата его открываются только тому, кто употребляет усилия над самим собою, чтобы сделаться достойным его» [Гладков: 323-1]. И далее: «Царство Небесное действительно берется силою, то есть дается только тому, кто ведет упорную борьбу со своими страстями, кто употребляет значительные усилия над собою, чтобы выйти победителем из этой борьбы» [Гладков: 323-2].

То, что пока неведомо герою, хорошо известно читателю: этот второй, духовный смысл обретения Царства Небесного (то есть спасения души) откроется Владимиру значительно позже, лишь после принятия им великого таинства Крещения. Именно тогда произойдет настоящий духовный переворот и не признававший для себя никаких моральных запретов человек вдруг преобразится, очистится и примет всем сердцем высший нравственный закон, заповеданный нам Спасителем.

\section{Примечания}

1 Среди них кандидатская диссертация О. И. Толстоуса «Поэтический мир К. Ф. Рылеева» [Толстоус], где подробно исследуются тематика и стихосложение, по-новому рассматривается эстетическая позиция поэта. Безусловный интерес представляет также докторская диссертация А. Г. Готовцевой «Публицистика К. Ф. Рылеева в историко-политическом контексте 1820-х гг.» [Готовцева], в которой объектом изучения является все творчество Рылеева, рассмотренное в различных контекстах: 
историко-политическом, биографическом и литературном. Особое внимание привлекают работы Т. А. Ложковой, в которых системно и глубоко раскрываются новые аспекты поэтики, а также подвергаются переосмыслению некоторые устоявшиеся представления о художественной организации произведений поэта [Ложкова, 2014, 2013, 2004].

2 Православие: словарь-справочник / изд. 2-е, испр. и доп. М.: Даръ, 2007. C. 709.

3 Там же. С. 160.

4 Былины // Русская народная поэзия. Эпическая поэзия: сборник. - Л.: Худож. лит., 1984. С. 14-105.

5 Рылеев К. Ф. Владимир Святый // Рылеев К. Ф. Полн. собр. стихотворений. Л.: Сов. писатель, 1971. С. 176. Далее ссылки на это издание приводятся в тексте статьи с указанием страницы в круглых скобках.

6 Полный церковно-славянский словарь (Репр. изд. 1900 г.) / сост. прот. Г. Дьяченко. М.: Отчий дом, 2006. С. 628-629.

7 Даль В. И. Толковый словарь живого великорусского языка: в 4 т. М.: Гос. изд-во иностранных и национальных словарей, 1955. Т. 4. С. 256-257.

8 Повесть временных лет. М.; Л.: Изд-во АН СССР, 1950. Ч. 1. Текст и перевод / подгот. текста Д. С. Лихачева; пер. Д. С. Лихачева и Б. А. Романова; под ред. В. П. Адриановой-Перетц. С. 257-258. («Литературные памятники»)

\section{Список литературы}

1. Архипова А. В., Ходоров А. Е. Примечания // Рылеев К. Ф. Полн. собр. стихотворений. - Л.: Сов. писатель, 1971. - С. 393-464.

2. Гинзбург Л. Я. О лирике. - Л.: Сов. писатель, 1974. - 408 с.

3. Гладков Б. И. Толкование Евангелия / репр. изд. - СПб.: б. и., 1913. - 768 с.

4. Добротолюбие избранное для мирян. - М.: Изд-во Сретенского монастыря, 2002. - 448 с.

5. Жирмунский В. М. Байрон и Пушкин. - Л.: Наука, 1978. - 424 с.

6. Захаров В. Н. Православные аспекты этнопоэтики русской литературы // Проблемы исторической поэтики. - Петрозаводск: Изд-во ПетрГУ, 1998. - Вып. 5. - С. 5-11 [Электронный ресурс]. - URL: http://poetica. pro/journal/article.php?id=2472 (10.12.2018). DOI: 10.15393/j9.art.1998.2472

7. Захаров В. Н. Русская литература и христианство // Проблемы исторической поэтики. - Петрозаводск: Изд-во ПетрГУ, 1994. - Вып. 3. C. 5-30 [Электронный ресурс]. - URL: http://poetica.pro/journal/article. php?id=2370 (10.12.2018). DOI: 10.15393/j9.art.1994.2370

8. Иларион (Алфеев), епископ. Таинство веры: введение в православное догматическое богословие. - 4-е изд. - Клин: Христианская жизнь, 2005. - $304 \mathrm{c}$.

9. Карамзин Н. М. История государства Российского: в 12 т. - М.: Наука, 1989. - Т. 1 / под ред. А. Н. Сахарова. - 640 с. 
10. Котляревский Н. А. Рылеев. - СПб.: б. и., 1908. - 240 с.

11. Левкович В. Я. Поэзия декабристов // История русской литературы: в 4 т. - Л.: Наука, 1981. - Т. 2. - С. 150-178.

12. Ложкова Т. А. Проблема субъектной организации «Дум» К. Ф. Рылеева // Известия Уральского государственного университета. Серия 2. Гуманитарные науки. - 2004. - № 31. - С. 206-217.

13. Ложкова Т. А. К вопросу о своеобразии конфликта в поэме К. Ф. Рылеева «Войнаровский» // Уральский филологический вестник. - 2013. № $1 .-$ С. $102-114$.

14. Ложкова Т. А. Байронический герой в поэмах Лермонтова и Рылеева: «Войнаровский» и «Измаил-бей» // Филологический класс. - 2014. № 3 (37). - С. 30-35.

15. Маслов В. И. Литературная деятельность К. Ф. Рылеева. - Киев: б. и., 1912. - $56 \mathrm{c}$.

16. Назаренко А. В. Древняя Русь на международных путях: междисциплинарные очерки культурных, торговых, политических отношений IX-XII веков. - М.: Языки русской культуры, 2001. - 784 c. (Studia historica)

17. Нейман Б. В. К. Ф. Рылеев. - М.: Гослитиздат, 1946. - 88 с.

18. Пигарев К. В. Жизнь Рылеева. - М.: Сов. писатель, 1947. - 255 с.

19. Платонов С. Ф. Лекции по русской истории / вступ. ст. А. Н. Фукса. М.: Высшая школа, 1993. - 736 с. («Историческое наследие»)

20. Стенник Ю. В. Драматургия русского классицизма. Трагедия // История русской драматургии: XVII - первая половина XIX века. - Л.: Наука, 1982. - C. 58-108.

21. Толстоус О. И. Поэтический мир К. Ф. Рылеева: дис. ... канд. филол. наук. - Смоленск, 2001. - 264 с.

22. Цейтлин А. Г. Творчество Рылеева. - М.: Изд-во АН СССР, 1955. - 304 с. 
Natalia P. Zhilina

(Kaliningrad, Russian Federation)

nzhilina@rambler.ru

\title{
The Idea of Salvation in Ryleev's Narrative Poem "Vladimir the Saint"
}

\begin{abstract}
Largely overlooked by scholars the religious context of Ryleev's writing became the focus of our research. The narrative poem "Vladimir the Saint" originally called duma was not published during the poet's lifetime. Being studied in an axiological aspect the central conflict of the poem is interpreted from a completely different angle. An analysis of the artistic structure covers a number of important points, that distinguish the duma's plot from the historical source, and prioritizes the opposition between Christianity and paganism that brings forward the antithesis of true and false values. The study clearly shows that the motif of conscience occupying the central place in the plot directly associates the ideological system to Christian anthropology. So, the transformation of a traditional impulse for the protagonist's separation from the world being usual for Romanticism elevates the idea of salvation as central and plot-generating in the poem. The final leaves the impression of incompleteness, thus, the title of the work anticipates future events and the poem depicts only the initial situation whereof the prince's path to holiness begins.
\end{abstract}

Keywords: Ryleev, duma, prince Vladimir, plot, motifs, Christianity, paganism

About the author: Zhilina Natalia P. - Doctor of Philology, Associate Professor, Professor of the Institute of Humanities, Immanuel Kant Baltic Federal University (ul. A. Nevskogo 14, Kaliningrad, 236016, Russian Federation)

Received: March 15, 2019

Date of publication: September 9, 2019

For citation: Zhilina N. P. The Idea of Salvation in Ryleev's Narrative Poem "Vladimir the Saint". In: Problemy istoricheskoy poetiki [The Problems of Historical Poetics], 2019, vol. 17, no. 3, pp. 25-43. DOI: 10.15393/j9. art.2019.6061 (In Russ.)

\section{References}

1. Arkhipova A. V., Khodorov A. E. Notes. In: Ryleev K. F. Polnoe sobranie stikhotvoreniy [Ryleev K. F. The Collection of Poems]. Leningrad, Sovetskiy pisatel' Publ., 1971, pp. 393-464. (In Russ.)

2. Ginzburg L. Ya. O lirike [About the Lyrics]. Leningrad, Sovetskiy pisatel' Publ., 1974. 408 p. (In Russ.)

3. Gladkov B. I. Tolkovanie Evangeliya [The Interpretation of the Gospel]. (Reprint Edition). St. Petersburg, 1913. 768 p. (In Russ.) 
4. Dobrotolyubie izbrannoe dlya miryan ["Philokalia" Chosen for the Laity]. Moscow, Sretensky Monastery Publ., 2002. 448 p. (In Russ.)

5. Zhirmunskiy V. M. Byron and Pushkin. Leningrad, Nauka Publ., 1978. 424 p. (In Russ.)

6. Zakharov V. N. Orthodox Aspects of Russian Literature Ethnopoetics. In: Problemy istoricheskoy poetiki [The Problems of Historical Poetics]. Petrozavodsk, PetrSU Publ., 1998, issue 5, pp. 5-11. Available at: http:// poetica.pro/journal/article.php?id=2472 (accessed on December 10, 2018). DOI: 10.15393/j9.art.1998.2472 (In Russ.)

7. Zakharov V. N. Russian Literature and Christianity. In: Problemy istoricheskoy poetiki [The Problems of Historical Poetics]. Petrozavodsk, PetrSU Publ., 1994, issue 3, pp. 5-30. Available at: http://poetica.pro/journal/article. php?id=2370 (accessed on December 10, 2018). DOI: 10.15393/j9.art.1994.2370 (In Russ.)

8. Ilarion (Alfeev), Bishop. Tainstvo very: vvedenie v pravoslavnoe dogmaticheskoe bogoslovie [A Sacrament of Faith: Introduction into Orthodox Dogmatic Theology]. Klin, Khristianskaya zhizn' Publ., 2005. 304 p. (In Russ.)

9. Karamzin N. M. Istoriya gosudarstva Rossiyskogo: $v 12$ tomakh [History of the Russian State: in 12 Vols]. Moscow, Nauka Publ., 1989, vol. 1. 640 p. (In Russ.)

10. Kotlyarevskiy N. A. Ryleev. St. Petersburg, 1908. 240 p. (In Russ.)

11. Levkovich V. Ya. The Poetry of the Decembrists. In: Istoriya russkoy literatury: $v 4$ tomakh [A History of Russian Literature: in 4 Vols]. Leningrad, Nauka Publ., 1981, vol. 2, pp. 150-178. (In Russ.)

12.Lozhkova T. A. Byronic Hero in the Poems by Lermontov and Ryleev: "Voynarovsky" and "Ismail-bey". In: Filologicheskiy klass [Philological Class], 2014, no. 3 (37), pp. 30-35. (In Russ.)

13. Lozhkova T. A. On the Peculiarities of the Conflict in Ryleev's "Voynarovsky". In: Ural'skiy filologicheskiy vestnik [Ural Journal of Philology], 2013, no. 1, pp. 102-114. (In Russ.)

14. Lozhkova T. A. The Problem of a Subjective Organization in K. F. Ryleev's "Thoughts". In: Izvestiya Ural'skogo gosudarstvennogo universiteta. Seriya 2. Gumanitarnye nauki [Izvestia. Ural Federal University Journal. Series 2. Humanities and Arts], 2004, no. 31, pp. 206-217. (In Russ.)

15. Maslov V. I. Literaturnaya deyatel'nost' K. F. Ryleeva [K. F. Ryleev's Literary Activity]. Kiev, 1912.56 p. (In Russ.)

16. Nazarenko A. V. Drevnyaya Rus' na mezhdunarodnykh putyakh: Mezhdistsiplinarnye ocherki kul'turnykh, torgovykh, politicheskikh otnosheniy IXXII vekov [Ancient Russia on an International Path: Interdisciplinary Essays of Cultural, Commercial, Political Relations of the 9th-12th Centuries]. Moscow, Yazyki russkoy kul'tury Publ., 2001. 784 p. (In Russ.)

17. Neyman B. V. K. F. Ryleev. Moscow, Goslitizdat Publ., 1946. 88 p. (In Russ.)

18. Pigarev K. V. Zhizn' Ryleeva [The Life of Ryleev]. Moscow, Sovetskiy pisatel' Publ., 1947. 255 p. (In Russ.)

19. Platonov S. F. Lektsii po russkoy istorii [Lectures on Russian History]. Moscow, Vysshaya shkola Publ., 1993. 736 p. (In Russ.) 
20.Stennik Yu. V. The Drama of Russian Classicism. Tragedy. In: Istoriya russkoy dramaturgii: XVII - pervaya polovina XIX veka [The History of Russian Dramatic Art: the 17th - First Half of the 19th Century]. Leningrad, Nauka Publ., 1982, pp. 58-108. (In Russ.)

21. Tolstous O. I. Poeticheskiy mir K. F. Ryleeva: dis. ... kand. filol. nauk [The Poetic World of K. F. Ryleev. PhD. philol. sci. diss.]. Smolensk, 2001. 264 p. (In Russ.)

22. Tseytlin A. G. Tvorchestvo Ryleeva [Ryleev's Works]. Moscow, Academy of Sciences of the USSR Publ., 1955. 304 p. (In Russ.) 